\title{
SABUN SUSU SAPI DENGAN PENAMBAHAN KULIT KAYU MANIS SEBAGAI ANTIBAKTERI
}

\author{
Ria Dinastuti ${ }^{1}$, Agung Abadi Kiswandono ${ }^{2}$, Siti Fatimah ${ }^{3 *}$ \\ ${ }^{1}$ Studi Teknik Kimia, Universitas Muhammadiyah Surakarta \\ ${ }^{2}$ Jurusan Kimia FMIPA Universitas Lampung, Bandar Lampung 35141 \\ ${ }^{3}$ Jurusan Teknik Kimia, Teknik, Universitas Muhammadiyah Surakarta
}

\section{$\underline{\text { sf120@ums.ac.id }}$}

\begin{tabular}{|l|}
\hline Artikel Info \\
Diterima \\
tanggal \\
21.12 .2020 \\
\\
Disetujui \\
publikasi \\
tanggal \\
30.04 .2021 \\
\\
Kata kunci : \\
Ekstraksi; \\
Kayu Manis; \\
NaOH; \\
Sabun Aroma; \\
Susu Sapi \\
\hline
\end{tabular}

ABSTRAK

Sabun terdiri dari campuran senyawa natrium dengan asam lemak yang dapat dimanfaatkan sebagai bahan pembersih tubuh, berbentuk padat, berbusa, dengan atau tanpa penambahan zat lain dan tidak menimbulkan iritasi pada kulit. Batang kayu manis digunakan untuk meningkatkan harga jual dari batang kayu manis, mengedukasi masyarakat bahwa kayu manis dapat digunakan sebagai bahan kosmetik selain sebagai bumbu masakan dan untuk ketersediaan tanaman kayu manis sangat melimpah dan mudah ditemui dilingkungan masyarakat. Penelitian ini bertujuan untuk membuat sabun susu sapi dengan penambahan kulit kayu manis sebagai aroma dengan menggunakan variasi pengaruh konsentrasi $\mathrm{NaOH}$, metode ekstraksi, dan karakteristik pada sabun yang akan dihasilkan menggunakan proses dingin. Sebelum ditambahakan, kulit kayu manis harus di ekstrak terlebih dahulu. Setelah di ekstraksi kemudian di olah menjadi sabun batang, sabun yang dihasilkan adalah sabun dengan konsentrasi $\mathrm{NaOH} 35 \%$ dengan metode ekstraksi pada suhu tinggi. Hasil uji karakteristik sabun dengan konsentrasi $35 \%$ dengan metode ekstraksi suhu tinggi menghasilkan kadar air sebesar 1,82\%, pH 10, stabilitas busa 88,24\%, alkali bebas $0,01 \%$, dan bilangan penyabunan $15,09 \%$. Sabun yang dihasilkan memenuhi standar SNI sabun batang 3532:2016.

\section{ABSTRACT}

Soap consists of a mixture of sodium compounds and fatty acids which can be used as a cleansing agent for the body, in the form of solid, foamy, with or without the addition of other substances, and does not irritate the skin. Cinnamon sticks are used to increase the selling price of cinnamon sticks, educate the public that cinnamon can be used as a cosmetic ingredient other than cooking spices, and to measure cinnamon plants that are very abundant and easily found in the community. This study aims to make cow's milk soap with the addition of cinnamon bark as an aroma by using variations in the influence of $\mathrm{NaOH}$ concentration, extraction method, and characteristics of the soap to be produced using the cold process. Before adding, cinnamon bark must be extracted first. After extraction and then processing it into bar soap, the resulting soap is a soap with a concentration of $35 \% \mathrm{NaOH}$ by the extraction method at high temperature. The results of the characteristic test of soap with a concentration of $35 \%$ with the high-temperature extraction method resulted in a water content of $1.82 \%$, a pH of 10 , foam stability of $88.24 \%, 0.01 \%$ free alkali, and a lathering number of $15.09 \%$. The resulting soap meets the SNI standard for bar soap 3532: 2016.

http://dx.doi.org/10.23960/aec.v6.i1.2021.p66-73

Anal.Environ.Chem. 


\section{PENDAHULUAN}

Sabun merupakan produk dasar saponifikasi. Berdasarkan sifat kimianya sebagai zat aktif permukaan anioniz (sulfaktan), sabun digunakan untuk membersihkan dan mencuci baik untuk badan dan juga pakaian (Firepomg and Mak-Mesah, 2011; Kerr-Pontes et al., 2006). Pada umumnya, pembuatan sabun ada dua metode, yaitu metode dingin (cold process) dan metode panas (hot process). Perbedaannya adalah dua metode ini terletak pada ada atau tidak adanya pemanasan setelah terjadinya proses saponifikasi. Sabun biasa memiliki kekurangan, yaitu dapat membuat kulit menjadi kering. Dari permasalahan tersebut maka perlunya bahan tambahan yang dapat melembabkan kulit serta beraroma herbal.

Susu berasal dari kambing dan sapi sehat dan bersih yang didapat dari proses pemerahan yang benar, memiliki kandungan alami yang tidak ditambah atau dikurangi sesuatu apaun dan belum melalui proses pengolahan apapun selain pendinginan. Susu memiliki sifat yang mudah rusak (perishable food) dan merupakan sumber protein hewani. Susu sapi memiliki kandungan asam lemak rantai panjang alam dalam jumlah besar, maka susu sapi bisa disabunkan. Secara kimiawi susu mempunyai komposisi air (87,20\%), lemak $(3,70 \%)$, protein $(3,50 \%)$, laktosa $(4,90 \%)$, dan mineral $(0,07 \%)$ (Sanam et al., 2014). Kelebihan sabun susu sapi yaitu tidak membuat kulit menjadi kering karena tidak mengandung sodium lauryl sulphate (SLS) sebagai bahan baku detergen (Kiswandono dkk., 2020)

Kayu manis berbau wangi dan berasa manis sehingga bisa digunakan sebagai bahan pembuat sirup dan rasa pedas sebagai penghangat tubuh. Kayu dari batang kayu manis bisa dijadikan sebagai bahan bangunan, meubel air, dan kayu bakar (Ferry, 2013). Komponen terbesar pada kayu manis adalah alkohol sinamat, kumarin, asam sinamat, sinamaldehid, antosinin dan minyak atsiri dan mengandung gula, protein, lemak sederhana, pektin dan lainnya (Al-Dhubiab, 2012). Ekstrak kulit batang Cinnamomum burmanii menghasilkan senyawa antioksida berupa polifenol (tanin, flavonoid) dan minyak atsiri golongan fenol. Kandungan utama minyak atsiri kayu manis adalah senyawa sinamaldehida dan eugenol (Ervina dkk., 2016).

Minyak nabati dapat didapat dari tanaman kelapa, kelapa sawit, jagung, kedelai, biji bunga matahari, dsb. Minyak nabati memiliki kandungan asam lemak, yaitu asam lemak jenuh (asam palmitat dan asam stearat) dan asam lemak tak jenuh (asam oleat atau Omega 9 dan asam linoleat atau Omega 6) (Utami, 2013). Setiap jenis asam lemak dapat memberikan 
fungsi yang berbeda dalam pembuatan sabun.Asam lemak dengan rantai karbon 12-14 baik untuk pembusaan, sedangkan asam lemak dengan rantai karbon 16-18 baik untuk kekerasan dan daya detergensi. Dalam penggunaan asam lemak rantai panjang $\mathrm{C}_{16}$ dan $\mathrm{C}_{18}$ akan menghasilkan sabun batang dengan struktur yang lebih kompak dan dapat mencegah atau memperlambat disintegrasi sabun saat terkena air, sedangkan asam lemak dengan rantai pendek yang memiliki kelarutan yang tinggi dalam menghasilkan busa pada sabun.

\section{METODE}

\section{Alat dan Bahan}

Alat yang digunakan adalah timbangan, blender, cetakan sabun, baskom, saringan, plastik wrap, dan spatula. Bahan yang digunakan adalah minyak sawit, minyak kelapa, susu sapi murni, ekstrak daun cengkeh, dan Natrium hidroksida.

\section{Prosedur}

\section{Metode Ekstraksi}

Ekstraksi Suhu Ruang : Kulit kayu manis di bersihkan kemudian jemur di bawah sinar matahari sampai kering. Kemudian kulit kayu manis di haluskan sampai halus. Berat bubuk kayu manis yang digunakan dalam pembuatan sabun susu sapi sebesar $2 \%$ dari total volume semua bahan yang digunakan.

Ekstraksi Suhu Tinggi : Bubuk kayu manis di timbang sebanyak 100 gram. Kemudian bubuk kayu manis di larutkan menggunakan aquadest sebanyak $1000 \mathrm{~mL}$ dan di panaskan sampai bubuk kayu manis larut. Setelah larut, ekstrak dipisahkan dengan ampasnya dengan cara disaring. Jumlah filtrate yang digunakan dalam bembuatan sabun susu sapi adalah $5 \mathrm{~mL}$.

\section{Pembuatan Sabun Susu Sapi}

Campurkan minyak kelapa $25 \mathrm{~mL}$ dan minyak kelapa sawit (palm oil) $100 \mathrm{~mL}$ ke dalam beaker sampai larut menggunakan hot plate stirrer tanpa menggunakan pemanasan. Kemudian tambahkan $60 \mathrm{~mL} \mathrm{NaOH}$, konsentrasi $\mathrm{NaOH}$ yang divariasi adalah 27,5\%; 30\%; 32,5\%; 35\%; dan 37,5\%. Kemudian aduk sampai larut, kurang lebih 5 menit. Setelah campuran minyak dan $\mathrm{NaOH}$ larut, tambahkan susu sapi segar $55 \mathrm{~mL}$ ke dalam beaker. Kocok sampai adonan menjadi trace kemudian ditambahkan bahan aditif yaitu ektrak batang kulit kayumanis. Proses ini tidak menggunakan pemanasan sama sekali. Masukan adonan ke dalam cetakan. Sabun dapat digunakan setelah 2-4 minggu setelahnya. 


\section{Uji kualitas sabun}

Uji kualitas sabun ditentukan menggunakan Standar Nasional Indonesia (SNI) sabun batang 3532:2016 berupa uji kadar air, derajat keasaman, stabilitas busa, alkali bebas, dan bilangan penyabunan. Selain itu, dilakukan uji antibakteri dengan metode difusi cakram untuk menentukan zona hambat pertumbuhan bakteri.

\section{HASIL DAN PEMBAHASAN}

Berdasarkan penelitian maka deperoleh hasil sabun dengan aroma khas kayu manis. Tetapi dalam pembuatan sabun susu sapi tidak dilakukan uji aroma sabun. Pada uji kualitas sabun berdasaran SNI sabun batang 3532:2016, didapatkan hasil seperti terlihat pada Tabel 1.

Tabel 1. Hasil uji kualitas sabun

\begin{tabular}{lrrrrrr}
\hline $\begin{array}{c}\text { Metode } \\
\text { Ekstraksi }\end{array}$ & $\begin{array}{c}\text { Kadar } \\
\text { NaOH (\%) }\end{array}$ & $\begin{array}{c}\text { Kadar Air } \\
(\%)\end{array}$ & $\begin{array}{c}\text { Derajat } \\
\text { Keasaman } \\
(\mathbf{p H})\end{array}$ & $\begin{array}{c}\text { Stabilitas } \\
\text { Busa (\%) }\end{array}$ & $\begin{array}{c}\text { Alkali } \\
\text { Bebas (\%) }\end{array}$ & $\begin{array}{c}\text { Bilangan } \\
\text { Penyabunan }\end{array}$ \\
\hline Bubuk Kayu & 27,5 & 3,28 & 11 & 63,16 & 0,03 & 44,52 \\
Manis & 30 & 2,08 & 10 & 86,96 & 0,02 & 35,62 \\
& 32,5 & 2,23 & 10 & 83,33 & 0,02 & 30,17 \\
& 35 & 3,04 & 11 & 75 & 0,03 & 30 \\
Ekstraksi & 37,5 & 3,38 & 11 & 66 & 0,02 & 32,32 \\
Suhu Tinggi & 27,5 & 3,05 & 10 & 100 & 0,03 & 30,23 \\
& 30 & 2,37 & 10 & 68 & 0,01 & 21,88 \\
& 32,5 & 2,79 & 10 & 80 & 0,01 & 20,12 \\
& 35 & 1,82 & 10 & 88,24 & 0,01 & 15,09 \\
& 37,5 & 1,97 & 10 & 66,67 & 0,03 & 19,6 \\
\hline
\end{tabular}

Pada Tabel 1 di atas, uji kadar air dilakukan untuk mengetahui apakah sabun yang dihasilkan memenuhi syarat mutu sabun berdasarkan SNI sabun batang 3532:2016 yaitu maksimal 15\%. Uji kadar air dilakukan dengan cara menimbang cawan yang berisi sabun sebagai berat awal. Kemudian dikeringkan dengan oven pada suhu $105^{\circ} \mathrm{C}$ selama $1 \mathrm{jam}$. Dari hasil analisa diperoleh untuk secara keseluruhan kadar air yang dihasilkan pembuatan susu sapi ini sudah memenuhi SNI yaitu maksimal 15\%. Untuk uji kadar air terbaik di peroleh dari proses ekstraksi suhu tinggi dengan kadar $\mathrm{NaOH} 35 \%$ sebesar $1,82 \%$.

Derajat keasaman $(\mathrm{pH})$ merupakan parameter yang sangat penting sebagai penentu apakah sabun layak digunakan atau tidak. Ini dikarenakan jika $\mathrm{pH}$ sabun yang dihasilkan memiliki sifat terlalu basa dapat mengakibatkan iritasi pada kulit dan itu tidak direkomendasikan untuk digunakan baik untuk sabun badan maupun sabun cuci tangan. 
Menurut syarat mutu sabun berdasarkan SNI sabun batang 3532:2016 adalah 9-11. Dari hasil penelitian, $\mathrm{pH}$ sabun yang dihasilkan rata-rata berkisar pada $\mathrm{pH}$ 10-11. Ini dapat disimpulkan bahwa sabun memenuhi syarat mutu SNI.

Penurunan stabilitas busa juga dipengaruhi oleh kandungan asam lemak bebas yang terdapat dalam sabun yang dihasilkan, karena asam lemak bebas yang terdapat dalam sabun dapat menghambat daya bersih dari sabun itu yang ditandai dengan sedikitnya busa yang dihasilkan. Penurunan stabilitas busa akibat meningkatnya rasio air ini diduga disebabkan oleh kandungan bahan aktif sabun yang lebih sedikit dibandingkan kandungan bahan selain sabun (air) (Wijana, 2009). Syarat stabilitas busa yang baik menurut Sameng (2013) adalah jika sabun yang sudah di vortex didiamkan \pm 5 menit, kemudian diperoleh stabilitas busa antara kisaran 60-70\%. Dari acuan tersebut maka dapat dinyatakan bahwa hasil uji stabilitas busa pada sabun susu sapi padat memenuhi syarat. Untuk uji stabilitas busa yang terbaik diperoleh dengan metode ekstraksi suhu tinggi dengan kadar $\mathrm{NaOH} \mathrm{35 \%} \mathrm{sebesar} \mathrm{88,24 \% .}$

Alkali bebas merupakan alkali yang tidak habis bereaksi dengan asam lemak pada proses pembuatan sabun. Kadar alkali bebas yang sesuai dengan syarat mutu SNI adalah maksimal $0,1 \%$. Semakin rendah residu alkali bebas maka semakin sempurna reaksi penyabunan dan efek antibakterialnya (Wijana, 2009). Dilihat dari Tabel 1, dapat disimpulkan bahwa sabun yang dihasilkan memenuhi syarat mutu sabun sesuai SNI. Untuk alkali bebas hasil terbaik diperoleh dengan metode ekstraksi suhu tinggi dengan kadar $\mathrm{NaOH}$ $30 \%$; $32,5 \%$; dan $35 \%$ sebesar $0,01 \%$.

Menurut Ketaren (1986), bilangan penyabunan yang ada dalam minyak dapat dipengaruhi oleh senyawa yang tak tersabunkan dalam minyak, seperti sterol, pigmen, hidrokarbon, dan tokoferol yang dapat mengurai kekuatan oksidasi terhadap ikatan tidak jenuh asam lemak. Ulasan tersebut juga diperkuat oleh Handayani dan Subagus (2008) bahwa, rendahnya bilangan penyabunan menandakan bahwa kandungan asam lemak total dalam lemak relatif lebih rendah. Ini menandakan bahwa minyak yang ditambahakan ekstrak memiliki kandungan asam lemak total yang relatif lebih rendah dari pada minyak kontrol. Hasil uji bilangan penyabunan yang terbaik diperoleh dari proses ekstraksi suhu tinggi dengan kadar $\mathrm{NaOH} 35 \%$ sebesar 15,09\%.

Pengujian antibakteri pada sabun susu sapi menggunakan metode difusi cakram. Metode ini dipilih karena memiliki kelebihan yaitu cepat, murah, umum digunakan, dan alat yang dibutuhkan mudah didapat dan di operasikan. Tujuan dari uji antibakteri ini untuk 
mengetahui apakah sabun susu sapi dengan ekstrak kayu manis dapat menghambat bakteri pada tubuh.

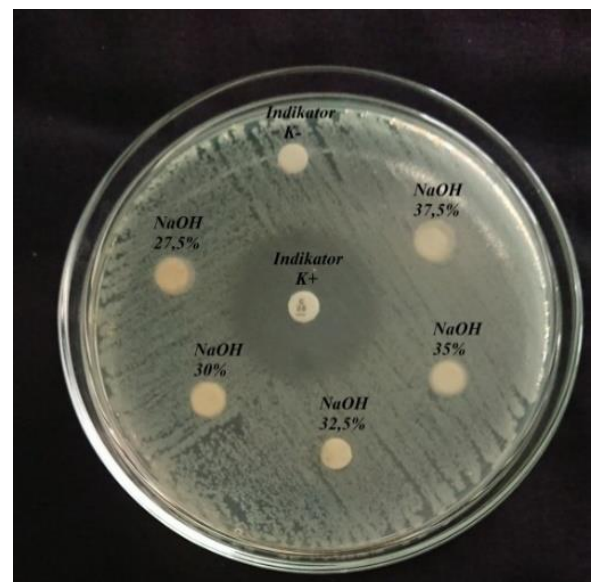

Gambar 1. Hasil Uji Antibakteri Sabun Susu Sapi Metode Ekstraksi Bubuk Kayu Manis dengan Bakteri Escherichia Coli

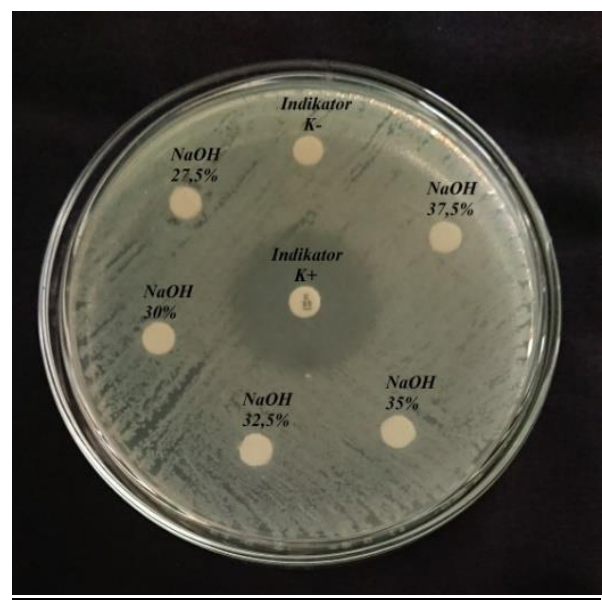

Gambar 2. Hasil Uji Antibakteri Sabun Susu Sapi Metode Ekstraksi Suhu Tinggi dengan Bakteri Escherichia Coli

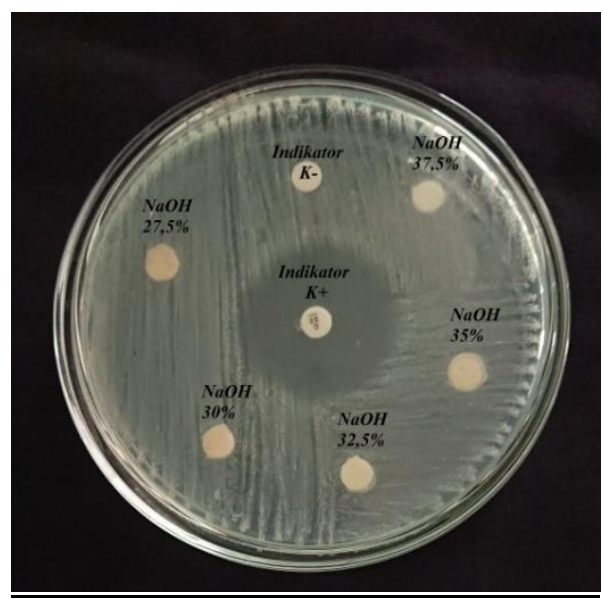

Gambar 3. Hasil Uji Antibakteri Sabun Susu Sapi Metode Ekstraksi Bubuk Kayu Manis dengan Bakteri Staphylococcus Aureus 


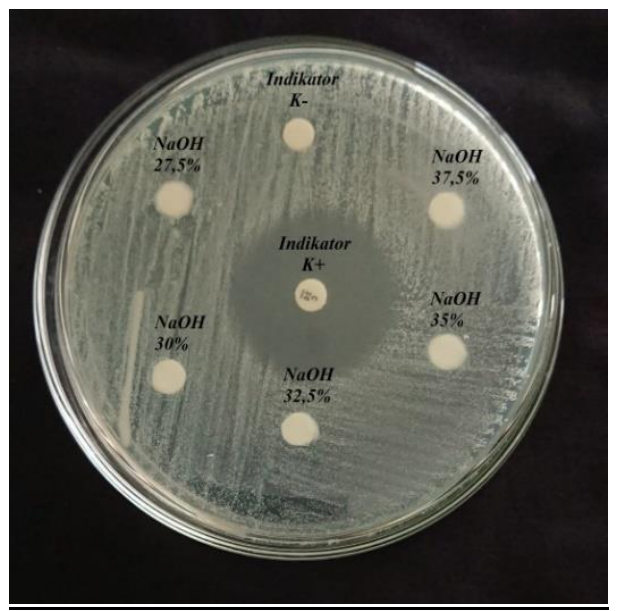

Gambar 4. Hasil Uji Antibakteri Sabun Susu Sapi Metode Ekstraksi Suhu Tinggi dengan Bakteri Staphylococcus Aureus

Dari hasil pengujian didapatkan bahwa sabun susu sapi dengan ekstrak kayu manis tidak memiliki zat antibakteri. Ini ditunjukkan tidak adanya zona rambat pada kertas cakram yang berisi senyawa uji, sedangkan untuk kertas cakram disk Chloramphenicol $30 \mathrm{mg}$ (Indikator $\mathrm{K}+$ ) yang berada di tengah terdapat zona rambat. Indikator $\mathrm{K}$ - dan Indikator $\mathrm{K}+$ sebagai patokan untuk pengujian anti bakteri. Ini bisa disebabkan kurangnya zat adiktif antibakteri sehingga sabun tidak memiliki zat antibakteri.

\section{KESIMPULAN}

Berdasarkan hasil penelitian, maka dapat disimpulkan bahwa pembuatan sabun susu sapi dengan penambahan kulit kayu manis dapat digunakan dengan metode ekstraksi suhu tinggi. Metode ini sangat baik karena sabun yang dihasilkan memiliki pH antara 10-11. Hasil terbaik diperoleh dengan menggunakan kadar $\mathrm{NaOH} 35 \%$, karena sabun yang dihasilkan lebih baik dari konsentrasi $\mathrm{NaOH}$ yang lain dan memenuhi syarat mutu sabun sesuai dengan SNI sabun batang 3532:2016. Ini dapat dilihat dari hasil uji kadar air diperoleh sebesar $1,82 \%, \mathrm{pH} 10$, stabilitas busa $88,24 \%$, alkali bebas $0,01 \%$, dan bilangan penyabunan $15,09 \%$.

\section{UCAPAN TERIMA KASIH}

Ucapkan terimakasih kepada LPPM UMS yang memberikan fasilitas untuk publikasi. Selain itu saya juga ucapkan terimakasih kepada pihak-pihak terkait dalam membantu saya menyelesaikan penelitian ini. 


\section{DAFTAR PUSTAKA}

Al-Dhubiab, B.E., 2012, Pharmaceutical Applications and Phytochemical Profile of Cinnamomum burmannii, Pharmacognosy Reviews., 6(12), 125-131.

BSN., 1994, Standar Mutu Sabun Mandi, Sni., 06-3532-1994.

Ervina M dkk., 2016, Comparison of In Vitro Antioxidant Activity of Infusion, Extract and Fractions of Indonesian Cinnamon (Cinnamomum Burmannii) Bark, International Food Research Journal., 23(3),1346-1350.

Ferry Y., 2013, Prospek Pengembangan Kayu Manis (Cinnamomum Burmanii L) di Indonesia, SIRINOV., Vol 1, No 1, April 2013 ( Hal : 11 - 20).

Firepomg, C.K. and Mak-Mesah, E.E., 2011, Chemical characteristic of toilet soap prepared from neem (Azadirachta indica A . Juss) seed oil, Asian Journal of Nutrition, Vol. 8 No. 9 , pp. 1325-1334.

Handayani, M.P. dan Subagus, W., 2008, Analisis Biji Ketapang (Terminalia catappa L.) sebagai Suatu Alternatif Sumber Minyak Nabati. Majalah Obat Tradisional.

Ketaren., 1986, Minyak dan Lemak Pangan, Universitas Indonesia, Jakarta.

Kerr-Pontes, L.R.S., Barreto, M.L., Evangelista, C.M.N., Rodrigues, L.C., Heukelbach, J, and Feldmeier, H., 2016, Socioeconomic, environmental, and behavioural risk factors for leprosy in North-east Brazil: Results of a case-control study, International Journal of Epidemiology., Vol. 35, No. 4, pp. 994-1000.

Kiswandono, A.A., Nurhasanah, dan Akmal, J., 2020, Workshop Peningkatan Kemampuan Pembuatan Detergen Cair Sebagai Upaya Mengaktifkan Pengurus PKK Desa Fajar Baru, Aptekmas: Jurnal Pengabdian kepada Masyarakat, Politeknik Negeri Sriwijaya.

Sameng, Mr., Wanhuseng, 2013, Formulasi Sediaan Sabun Padat Sari Beras (Oryza sativa) sebagai Antibakteri terhadap Staphylococcus epidermis, Fakultas Farmasi Universitas Muhammadiyah, Surabaya.

Sanam, A.B., Bagus, I \& Swacita, N., 2014. Ketahanan Susu Kambing Peranakan Ettawah Post-Thawing pada Penyimpanan Lemari Es Ditinjau dari Uji Didih dan Alkohol., 3(1), pp 1-8.

Standar Nasional Indonesia (SNI) 3532:2016., 2016, Standar Mutu Sabun Padat, BSN

Utami, W., 2013, Sintesis Biodiesel menggunakan Katalis yang Bersumber dari Cangkang Kerang Darah (Anadara granosa). Skripsi. Jurusan Kimia Fakultas Matematika dan Ilmu Pengetahuan Alam. Universitas Riau, Pekanbaru.

Wijana, S., Soemarjo. T. Harnawi., 2009, Studi Pembuatan Sabun Mandi Cair dari Daur Ulang Minyak Goreng. Jornal Teknologi Pertanian, Vol. 11, No. 2 (Agustus 2010) 114-122 